\title{
EXAMINING THE EFFECTS OF PSYCHIATRIC SYMPTOMS, BRAIN INJURY SYMPTOMS, AND LOW SELF-CONTROL ON THE PLACEMENT OF INMATES IN ADMINISTRATIVE SEGREGATION AND THEIR RISK FOR SUICIDAL IDEATION
}

\author{
Sriram Chintakrindi \\ California State University, Stanislaus \\ E-mail: schintakrindi@csustan.edu \\ Joel Capellan \\ Rowan University \\ Jeremy R. Porter \\ Brooklyn College, CUNY
}

M. Blake Wilson

California State University, Stanislaus

Suditi Gupta

California State University, Stanislaus, Modesto Junior College

\begin{abstract}
Objective: In this study, we are interested in understanding the predictive effects of psychiatric symptoms, brain injury symptoms, and criminological factors on inmate $(\mathrm{N}=270)$ risk for placement in administrative segregation and their expression of suicidal ideation.

Methods: Using a case-control design, this study seeks to understand the psychological and behavioral risk-profiles of inmates being placed in administrative segregation and those with suicidal ideation. More specifically, we are trying to understand the magnitude of the effect that psychiatric symptoms, brain injury symptoms, and low self-control characteristics has on the risk of inmates being placed in administrative segregation and their risk for suicidal ideation.

Results: We found that factor scores for psychiatric symptoms and low self-control levels significantly increase the risk of inmates expressing suicidal ideation when compared to alternative predictive factors.
\end{abstract}

Keywords: psychiatric symptoms, brain injury, low self-control, administrative segregation, suicidal ideation 


\section{INTRODUCTION}

Identifying and understanding the premorbid and precipitating risk factors of inmate placement in administrative segregation and inmate risk for suicidal ideation is a growing area of interest for criminal justice researchers and practitioners who are seeking to implement evidence-based practices to improve institutional safety and prevent adverse behaviors among inmates. An estimated 80,000 to 100,000 inmates in 2014, in both State and Federal custody, in jails and prisons, were placed in some form of "solitary confinement," "secure housing unit," or "administrative segregation," due to the threat or danger they posed to themselves, staff, or other inmates. Administrative segregation consists of a 22 to 24 -hour a day lockdown and confinement of the inmate in a cell size that is measuring 6 to 8 feet in width, 10 feet in length, and has an 8-foot ceiling (Lanes, 2011).

Inmates in administrative segregation are under close observation by correctional staff, their communication privileges are highly restricted, and movement is confined to either their cell or to a closely monitored confined space for hygiene and exercise. Inmate placement and length of time in administrative segregation is often at the discretion of correctional staff and administrators based on an assessment of perceived threats or evidence of wrongdoing (Lanes, 2011).

A growing body of studies are highlighting the deleterious short-term and long-term physiological and psychological outcomes that prolonged placement in administrative segregation has on inmate physical and mental health. Additionally, with the increasing utilization of administrative segregation as a leading form of punitive institutional punishment, and suicide being one of the leading causes of death in U.S. correctional institutions, we are interested in understanding if identical models of risk can be applied to predicting both outcome areas. Furthermore, we are interested in understanding whether the results from our study would allow us to re-conceptualize the very notion of placement of inmates in administrative segregation as a variant form of parasuicide. Jenkins, Hale, Papanastassiou, Crawford, and Tyrer (2002) found that individuals who engaged in parasuicide were at 100 times greater risk of engaging in suicide compared to the general population.

\section{LITERATURE REVIEW}

There is only one really serious philosophical problem, and that is suicide. Deciding whether or not life is worth living is to answer the fundamental question in philosophy. All other questions follow from that (Camus, Myth of Sisyphus, 3).

Durkheim (1897) examined four differing types of suicide and their relationship to empirically measurable sociological constructs (Chintakrindi \& Porter, 2016). Durkheim (1897) describes how prisoners, slaves, and those who are overworked are at risk of engaging in fatalistic suicide. Durkheim (1897) states that fatalistic suicide is: "the suicide deriving from excessive regulation, that of person with futures pitilessly blocked and passions violently choked by oppressive discipline." The fatalistic typology of suicide that is described by Durkheim (1897) is the result of excessive, rigid, and forced discipline being unduly imposed on an individual which results in great strain and

stress and can only be remedied through suicide. 
We hypothesize that there is a strong theoretical connection between examining risk for both inmate placement in administrative segregation and inmate risk for suicidal ideation as what Durkheim (1897) would describe as "fatalistic suicide" or Linehan and Nielson's (1981) description of parasuicide. Therefore, we argue that administrative segregation can be conceptualized as a form of social suicide for an inmate who, through their involuntary or deliberate violation of prison rules, are in fact electing themselves to be removed from the general population as a possible adverse reaction to the highly disciplined and rigid environment of being incarcerated (Durkheim, 1897). For some inmates, it may be extremely burdensome to have to navigate the complex and dynamic social environment and rules and regulations of jail and prison environments. Those inmates may view administrative segregation as a more attractive alternative rather than having to remain among an increasingly hostile, overcrowded, and privacy deprived general inmate population.

\section{Reviewing Psychiatric Symptoms among Inmates}

Hagan et al. (2017) found that among inmates who reported having a history of solitary confinement, $40 \%$ also reported having symptoms of PTSD, considerably higher than the prevalence rates found among general population of inmates with no history of solitary confinement and demonstrating symptoms of PTSD (16\%). Furthermore, O'Keefe (2008) examined offender needs across 10 areas and found that inmates in administrative segregation had statistically significant higher needs levels compared to the general population in self-destructive behaviors (32\% v. 15\%), assaultive behavior ( $70 \%$ v. $43 \%$ ), qualifying mental illness ( $25 \%$ v. $15 \%)$, and psychological issues (37\% v. 23\%). Among the many symptoms caused by solitary confinement, Grassian (2006) notes that The Specific Psychiatric Syndrome Associated with Solitary Confinement can be characterized by the following symptoms: (1) hyperresponsivity to external stimuli, (2) perceptual distortions, illusions, and hallucinations, (3) panic attacks, (4) difficulties with thinking, concentration, and memory, (5) intrusive obsessional thoughts, (6) overt paranoia, (7) and problems with impulse control.

An example of a study that examines premorbid or precipitating factors leading to placement of inmates in solitary confinement is the study conducted by Lanes (2011), where the researcher examined whether inmates with a history of self-injurious behaviors compared to inmates who never engage in self-injurious behaviors are probabilistically more likely to be placed in long-term maximum-security administrative segregation. Lanes (2011) describes how inmates who are designated as needing mental health treatment are disproportionally involved in a higher-percentage of prison misconduct. At least $48 \%$ of the prisoners executed in the United States from 2000 to 2015 suffered from a mental illness, which were most likely developed prior to their incarceration and death sentence (Baumgartner el al., 2017).

Using a risk model that examines inmate psychopathology and developmental history related to impulsivity, poor cognition, poor frustration tolerance, and maladaptive behaviors, Lanes (2011) hypothesizes that self-injurious behavior predicts inmate placement in maximum-security administrative segregation. Findings from this study indicate that inmates that engage in self-injurious behavior have a higher likelihood of being placed in solitary confinement compared to non-self-injurious behavior inmates. Findings from this study also indicate that inmates who engage in self-injurious behaviors are also more likely to harm others and damage property (Lanes, 2011). 
Kaba et al. (2014) describe how inmates often arrive in correctional settings with a pre-existing history of mental illness and history of self-harm. One-third of inmates admitted to New York City jails, for example, receive care for mental health issues. Kaba et al. (2014) conclude that there is a strong relationship between inmate placement in solitary confinement and engagement in self-harming behaviors. More specifically, they found that individuals with a severe mental illness and aged 18 or younger were strongly predictive of self-harm and potentially fatal self-harm (Kaba et al., 2014). Additionally, Kaba et al. (2014) observed a compounding effect, where inmates currently placed in solitary confinement will earn additional time in solitary confinement for disciplinary infractions, such as those related to destruction of property on the one hand, and threatening, or violent behavior towards staff on the other.

Metzner and Fellner (2010) describe how suicides occur disproportionately more frequently in segregation units than any other type of institutional setting within prisons. Furthermore, they describe how mentally ill prisoners decompensate and that their symptoms exacerbate when placed in isolation. Inmates often require considerable crisis care and psychiatric hospitalization, but many of them do not recover as long as they remain in isolation or administrative segregation (Haney \& Zimbardo, 1998; Haney, 2003). Both Kaba et al. (2014) and Metzner and Fellner (2010) highlight the extent to which premorbid symptoms of psychiatric illness can become exacerbated by placement of at-risk inmates in solitary confinement.

\section{Reviewing Brain Injury Symptoms among Inmates}

Slaughter, Fann, and Ehde (2003) report that the prevalence of traumatic brain-injury (TBI) among inmates varies based on the correctional institutional setting. In prison diversion programs, $50 \%$ of probationers exhibit symptoms of TBI, $22 \%$ among forensic psychiatric hospital patients, $87 \%$ among jail inmates, $36-86 \%$ among prisoners, and nearly $100 \%$ among death row inmates (Lewis, Pincus, Feldman, Jackson, \& Bard, 1986). TBI is often characterized as an "invisible disability" because its presentation and symptoms often go unnoticed due to the lack of external physical indicators other than a concussion, loss of consciousness, or cognitive impairments. A growing body of research on the neuropsychiatric etiology of head-injury and organic brain disease among inmates are seeking to profile the premorbid presentation of symptoms and behavioral characteristics that precede inmate placement in correctional settings (Sung, 2006; Sung, Mellow, \& Mahoney, 2010; Sung, 2010). Research on inmates offers considerable evidence that a neuropsychological approach to profiling premorbid and precipitating characteristics of head-injury are linked to self-harm and suicidal ideation (Gunter et al., 2013). Siegler, Rosner, MacDonald, Ford, \& Venters (2017) discuss how widespread violence in the prison and jail system are likely sources of neuroanatomical and neurodegenerative head injuries among inmates that may be linked to CTE. However, observations and diagnosis of CTE is only possible by examining deceased athletes and inmates.

Gunter et al. (2013) found high prevalence (44\%) of suicidal ideation and self-harm behaviors among offenders under correctional supervision in the community. Furthermore, their research reveals that brain-injury was statistically significantly associated with suicidal ideation and suicide-related behaviors among inmates sentenced to community corrections. However, they argue that the relationship between head-injury and suicidal ideation may be spurious, because accidental 
injury, poverty, and poorer health status among individuals who are substance users may pose an increasing offender risk for both head-injury and suicidal ideation.

\section{General Theory of Crime: Low Self-Control}

Low self-control theory allows for a closer examination of predictive risk factors for inmate placement in administrative segregation and suicidal ideation using assumptions based on individual level trait differences that are stable across the life course. Low self-control traits are a set of static-factors that are highly predictive of patterns of failed socialization and criminal behavior throughout the life course. Gottfredson and Hirschi (1990) summarize the characteristics of an individual with low self-control as having traits that are: (1) impulsive, (2) self-centered, (3) risk-taking, (4) preference for physical activities, (5) preference for simple tasks, and (6) having a volatile temperament. Individuals who are unconcerned about the long-term consequences of their actions and who are unable to delay gratification are predisposed to criminal behavior. Individuals with these traits can be unidimensionally characterized as having low self-control and are predicted to commit crimes involving fraud, force, and analogous behaviors (e.g. abusing drugs, drinking, smoking, gambling, and illicit sex). Grasmick et al. (1993) hypothesize that the six components can be measured and will unidimensionally align to produce a single measure of low self-control.

\section{AIM OF THE STUDY, RESEARCH QUESTIONS AND HYPOTHESIS}

\section{Aim of the Study}

Limited research is available on inmate risk for suicidal ideation, and it remains an elusive task due to the wide variability of the socio-demographic characteristics of individuals being incarcerated and the difficulties with accessing data on inmate placement in administrative segregation. In this study, we are interested in examining whether theoretical neuropsychiatric and criminological factors are contributing to inmate propensity for social exclusion through placement in administrative segregation and engaging in suicidal ideation. The extant literature highlights how psychiatric symptoms, brain injury, and low self-control characteristics contribute to criminality and deviance. However, gaps in the current literature fail to address how these same factors may contribute toward inmate propensity for social exclusion through placement in solitary confinement and suicidal ideation.

\section{Research Question}

We are interested in exploring and testing whether unidimensional constructs for psychiatric symptoms, brain injury, and low self-control are predictive of (1) inmate placement in administrative segregation and (2) inmate suicidal ideation. 


\section{Hypothesis}

Given our review of the extant literature, we hypothesize that psychiatric symptoms, brain injury symptoms, and low self-control characteristics will be equally and statistically significantly predictive of inmate placement in administrative segregation. Also, we hypothesize that psychiatric symptoms, brain injury symptoms, and low self-control characteristics will be equally and statistically significantly predictive of inmate risk for suicidal ideation.

\section{METHODS}

\section{Data}

For this study, we conducted a secondary data analysis of the Evaluation of the Psychological Effects of Administrative Segregation in Colorado data, which was collected between the years 2007 and 2010 (O'Keefe and Klebe, 2014). This data is publicly available and accessible using the Inter-university Consortium for Political and Social Research (ICPSR) website.

\section{Sample}

Inmates recruited and participating in the study were aged 18 or older, male, and English speaking. Inmate data in this study was collected from two different facilities: (1) Colorado State Penitentiary and (2) San Carlos Correctional Facility (O'Keefe and Klebe, 2014). Inmates were compensated with $\$ 10$ in their Colorado Inmate Phone System account for each of the baseline and follow-up testing sessions they completed. A total of 1083 inmates were screened for eligibility to participate in the study. However, 813 inmates were designated as ineligible, refused participation, not selected, or were removed from the study (O'Keefe and Klebe, 2014). Only 270 (24.9\%) inmates of the 1083 inmates screened for eligibility, consented to participate in the study at baseline. O'Keefe et al. (2010) provide summary statistics in the sampling section of the removed cases and data in their final report for this study. Of the 270 inmates agreeing to participate in the study, 237 (87.8\%) consented and completed all tests and 33 (12.2\%) withdrew their consent, were paroled, or released after at least one test.

\section{Study Design}

In this study, we use a retrospective case-control study design, to compare our outcomes of interest among inmates (cases) who have been (1) placed in administrative segregation or (2) have suicidal ideation with inmates who do not present these outcomes (controls). The retrospective case-control study design will allow us to compare how frequently the inmates in this study have been exposed to specific risk factors of interest (i.e. psychiatric symptoms, brain injury symptoms, and low self-control characteristics) in each group in order to analyze the relationship between our specified risk-factors and outcomes of interest. 


\section{Ethical Considerations}

The Institutional Review Board at California State University, Stanislaus, designates this study as exempt from review because this study uses secondary data that is publicly available from the Inter-university Consortium for Political and Social Research. All identifying information of research participants in this study is unavailable or de-identified in the publicly available datasets (O'Keefe and Klebe, 2014).

\section{Measures}

In the longitudinal study conducted by O'Keefe and Klebe (2010), they administered 14 psychological tests to inmates at six different time periods in 12 months. For the purposes of our secondary data analysis, we examine a select number of items from each of the following psychological instruments within the datasets made available on ICPSR: Brief Symptom Inventory, Coolidge Correctional Inventory, Expanded Brief Psychiatric Rating Scale, Level of Service Inventory-Revised, Prison Behavior Rating Scale, Prison Symptom Inventory (PSI), \& Trauma Symptom Inventory (TSI).

\section{Outcome Variables}

For this study, we examine two different outcome variables. The institutional placement status of the inmate is recoded general population (0) or administrative segregation (1). Our measure of suicidal ideation is self-reported: I have said I would kill myself, or tried to, more than once in my life is coded never (0) and yes, at least one time (1).

\section{Predictor Variables}

In this study, we examine three distinct theoretical predictor variables: psychiatric symptoms, brain injury symptoms, and low self-control characteristics.

\section{1) Psychiatric Disorder Symptoms Factor Score}

Results from the factor analysis of the 9-items, listed in table 1, indicate that there is a unidimensional construct for measuring the severity of psychiatric disorder symptoms. The exploratory factor analysis includes a reliability analysis that allows us to examine the internal consistency of the 9-items in terms of fitting a unidimensional construct. The factor score results for psychiatric disorder symptoms indicate that the 9 -items have an alpha reliability of 0.73 and that the one factor solution explains $34.0 \%$ of the total variation in those items as a linear combination. 
Table 1. Descriptive statistics of psychiatric symptoms factor score

\begin{tabular}{|c|c|c|c|c|c|c|c|c|}
\hline $\begin{array}{l}\text { Psychiatric disorder symptoms } \\
N=270\end{array}$ & $\begin{array}{l}\text { Not present } \\
(\mathrm{n}, \%)\end{array}$ & $\begin{array}{l}\text { Very mild } \\
\quad(n, \%)\end{array}$ & $\begin{array}{l}\text { Mild } \\
(\mathrm{n}, \%)\end{array}$ & $\begin{array}{l}\text { Moderate } \\
\quad(n, \%)\end{array}$ & $\begin{array}{c}\text { Moderately } \\
\text { Severe } \\
(\mathrm{n}, \%)\end{array}$ & $\begin{array}{l}\text { Severe } \\
(\mathrm{n}, \%)\end{array}$ & $\begin{array}{c}\text { Extremely } \\
\text { Severe } \\
(n, \%)\end{array}$ & $\begin{array}{l}\text { Factor } \\
\text { Loading }\end{array}$ \\
\hline 1. Anxiety & $104,38.5$ & $74,27.4$ & $57,21.1$ & $24,8.9$ & $9,3.3$ & $1,0.4$ & $1,0.4$ & 0.666 \\
\hline 2. Depression & $98,36.3$ & $83,30.7$ & $49,18.1$ & $34,12.6$ & $4,1.5$ & $2,0.7$ & $0,0.0$ & 0.399 \\
\hline 3. Elevated mood & $233,86.3$ & $2,10.4$ & $6,2.2$ & $1,0.4$ & $2,0.7$ & $0,0.0$ & $0,0.0$ & 0.688 \\
\hline 4. Grandiosity & $246,91.1$ & $15,5.6$ & $4,1.5$ & $2,0.7$ & $3,1.1$ & $0,0.0$ & $0,0.0$ & 0.556 \\
\hline 5. Suspiciousness & $170,63.0$ & $44,16.3$ & $35,13.0$ & $11,4.1$ & $6,2.2$ & $3,1.1$ & $1,0.4$ & 0.683 \\
\hline 6. Hallucinations & $190,70.4$ & $40,14.8$ & $18,6.7$ & $15,5.6$ & $5,1.9$ & $2,0.7$ & $0,0.0$ & 0.657 \\
\hline 7. Unusual thought content & $216,80.0$ & $27,10.0$ & $14,5.2$ & $9,3.3$ & $1,0.4$ & $3,1.1$ & $0,0.0$ & 0.647 \\
\hline 8. Bizarre behavior & $238,88.1$ & $18,6.7$ & $9,3.3$ & $4,1.5$ & $1,0.4$ & $0,0.0$ & $0,0.0$ & 0.614 \\
\hline 9. Self-neglect & $246,91.1$ & $13,4.8$ & $10,3.7$ & $1,0.4$ & $0,0.0$ & $0,0.0$ & $0,0.0$ & 0.670 \\
\hline
\end{tabular}

\section{2) Brain Injury Symptoms Factor Score}

Results from the factor analysis, of the 18-items, listed in Table 2, indicate that there is a unidimensional construct for measuring the severity of brain injury symptoms. The exploratory factor analysis includes a reliability analysis that allows us to examine the internal consistency of the 18-items in terms of fitting a unidimensional construct. The factor score results for brain injury symptoms indicate that the 18 -items have an alpha reliability of 0.91 and that the one factor solution explains $41.2 \%$ of the total variation in those items as a linear combination.

Table 2. Descriptive statistics of brain injury symptoms factor score

\begin{tabular}{|c|c|c|c|c|c|}
\hline $\begin{array}{l}\text { Brain injury and disease symptoms } \\
N=270\end{array}$ & $\begin{array}{l}\text { Strongly } \\
\text { false } \\
(n, \%)\end{array}$ & $\begin{array}{l}\text { More false } \\
\text { than true } \\
(n, \%)\end{array}$ & $\begin{array}{l}\text { More true } \\
\text { than false } \\
\quad(n, \%)\end{array}$ & $\begin{array}{l}\text { Strongly } \\
\text { true } \\
(\mathrm{n}, \%)\end{array}$ & $\begin{array}{l}\text { Factor } \\
\text { Loading }\end{array}$ \\
\hline 1. I think my memory has gotten worse in the past few years. & $95,35.2$ & $69,25.6$ & $63,23.3$ & $43,15.9$ & 0.601 \\
\hline 2. I often forget to do things I am supposed to do. & $101,37.4$ & $91,33.7$ & $56,20.7$ & $22,8.1$ & 0.555 \\
\hline 3. I often forget what I am about to say. & $109,40.4$ & $91,33.7$ & $53,19.6$ & $17,6.3$ & 0.637 \\
\hline 4. I habve trouble thinking straight. & $94,34.8$ & $87,32.2$ & $73,27.0$ & $16,5.9$ & 0.666 \\
\hline 5. I have noticed a change in my sense of taste or smell. & $130,48.1$ & $61,22.6$ & $60,22.2$ & $19,7.0$ & 0.547 \\
\hline 6. I have been told that the way I speak is strange or unclear. & $119,44.1$ & $84,31.1$ & $49,18.1$ & $18,6.7$ & 0.411 \\
\hline 7. I have problems with my balance. & $176,65.2$ & $64,23.7$ & $24,8.9$ & $6,2.2$ & 0.637 \\
\hline 8. I hear voices or see things that are not really there. & 162,60 & $32,11.9$ & $31,11.5$ & $45,16.7$ & 0.566 \\
\hline 9. I think there is something wrong with my mind. & $117,43.3$ & $50,18.5$ & 54,20 & $49,18.1$ & 0.642 \\
\hline 10. I have headaches. & $77,28.5$ & $73,27.0$ & $78,28.9$ & $42,15.6$ & 0.325 \\
\hline 11. I am unhappy most of the time. & 81,30 & $78,28.9$ & $67,24.8$ & $44,16.3$ & 0.691 \\
\hline 12. I have dizzy spells. & $157,58.1$ & $65,24.1$ & $35,13.0$ & $13,4.8$ & 0.600 \\
\hline 13. I don't find much pleasure in life. & $96,35.6$ & $90,33.3$ & $54,20.0$ & $30,11.1$ & 0.783 \\
\hline 14. I fail to listen to people when they talk to me. & $90,33.3$ & $103,38.1$ & $58,21.5$ & $19,7.0$ & 0.741 \\
\hline 15. I have trouble following instructions. & $105,38.9$ & $94,34.8$ & $61,22.6$ & $10,3.7$ & 0.726 \\
\hline 16. I have trouble getting organized. & $112,41.5$ & $96,35.6$ & $46,17.0$ & $16,5.9$ & 0.701 \\
\hline 17. I am easily distracted. & $65,24.1$ & $74,27.4$ & $104,38.5$ & $27,10.0$ & 0.630 \\
\hline 18. I am forgetful. & $86,31.9$ & $92,34.1$ & $68,25.2$ & $24,8.9$ & 0.609 \\
\hline
\end{tabular}


Sriram Chintakrindi, Joel Capellan, Jeremy R. Porter, M. Blake Wilson, Suditi Gupta: Examining the Effects of...

\section{3) Low Self-Control Characteristics Factor Score}

Results from the factor analysis of the 22-items, listed in table 3 , indicate that there is a unidimensional construct for measuring the degree of low self-control characteristics. The exploratory factor analysis includes a reliability analysis that allows us to examine the internal consistency of the 22 -items in terms of fitting a unidimensional construct. The factor score results for low self-control characteristics indicate that the 22 -items have an alpha reliability of 0.76 and that the one factor solution explains $21.8 \%$ of the total variation in those items as a linear combination.

Table 3. Descriptive statistics of low self-control characteristics factor score

\begin{tabular}{|c|c|c|c|c|c|}
\hline $\begin{array}{l}\text { Low self-control characteristics } \\
N=270\end{array}$ & $\begin{array}{c}\text { Strongly } \\
\text { false } \\
(n, \%)\end{array}$ & $\begin{array}{l}\text { More false } \\
\text { than true } \\
(n, \%)\end{array}$ & $\begin{array}{l}\text { More true } \\
\text { than false } \\
(n, \%)\end{array}$ & $\begin{array}{c}\text { Strongly } \\
\text { true } \\
(n, \%)\end{array}$ & $\begin{array}{l}\text { Factor } \\
\text { Loading }\end{array}$ \\
\hline 1. I am afraid to do things that might get me arrested. & $60,22.2$ & $83,30.7$ & $71,26.3$ & $56,20.7$ & 0.711 \\
\hline $\begin{array}{l}\text { 2. I have been very thoughtless in my spending money, or sex, drug } \\
\text { use, shoplifting, reckless driving, or binge eating. }\end{array}$ & $52,19.3$ & $36,13.3$ & $97,35.9$ & $85,31.5$ & 0.571 \\
\hline 3. I am restless. & $65,24.1$ & $57,32.2$ & $86,31.9$ & $32,11.9$ & 0.453 \\
\hline 4. I have trouble waiting my turn in line. & $112,41.5$ & $83,30.7$ & $50,18.5$ & $25,9.3$ & 0.611 \\
\hline 5. I fail to finish jobs even when I have the skill to do them. & $121,44.8$ & $108,40.0$ & $29,10.7$ & $12,4.4$ & 0.619 \\
\hline 6. I have trouble understanding what I read. & $121,44.8$ & $88,32.5$ & $42,15.5$ & $19,7.03$ & 0.515 \\
\hline 7. I put off or delay making decisions. & $71,26.3$ & $121,44.8$ & $66,24.4$ & $12,4.4$ & 0.693 \\
\hline 8. I lose things necessary to complete tasks. & $134,49.6$ & $101,37.4$ & $30,11.1$ & $5,1.9$ & 0.492 \\
\hline 9. Some people say that I take too many chances. & $42,15.6$ & $63,23.3$ & $95,35.2$ & $70,25.9$ & 0.616 \\
\hline 10. I have traveled around without job, a clear goal, or a travel plan. & $80,29.6$ & $62,23.0$ & $70,25,9$ & $58,21.5$ & 0.567 \\
\hline 11. I like new and risky things. & $35,13.0$ & $57,21.1$ & $118,43.7$ & $60,22.2$ & 0.507 \\
\hline 12. I get by in my life without help from others. & $56,20.7$ & $61,22.6$ & $103,38.1$ & $50,18.5$ & 0.715 \\
\hline $\begin{array}{l}\text { 13. I don't want and don't like people to be close to me (including my } \\
\text { family). }\end{array}$ & $119,44.1$ & $81,30.0$ & $39,14.4$ & $31,11.5$ & 0,679 \\
\hline 14. It really bothers me when I'm not the center of attention. & $166,61.5$ & $76,28.1$ & $22,8.1$ & 6. 2.2 & 0.586 \\
\hline 15. I usually tell others to do things the way I want them to be done. & $48,17.8$ & $73,27.0$ & $110,40.7$ & $39,14.4$ & 0.717 \\
\hline 16. I think of myself as a loner. & $65,24.1$ & $60,22.2$ & $73,27.0$ & $72,26.7$ & 0.563 \\
\hline 17. People have accused me of being self-centered. & $77,28.5$ & $79,29.3$ & $90,33.3$ & $24,8.9$ & 0.508 \\
\hline 18. I usually have heavy and up and down relationships. & $68,25.2$ & $73,27.0$ & $93,34.4$ & $36,13.3$ & 0.620 \\
\hline 19. When people criticize me, I almost never get angry. & $64,23.7$ & $104,38.5$ & $79,29.3$ & $23,8.5$ & 0.626 \\
\hline 20. People make me angry. & $39,14.4$ & $92,34.1$ & $94,34.8$ & $45,16.7$ & 0.64 \\
\hline 21. My moods change quite fast. & $56,20.7$ & $73,27.0$ & $83,30.7$ & $58,21.5$ & 0.593 \\
\hline 22. I've had a lot of temper tantrums. & $116,43.0$ & $70,25.9$ & $62,23.0$ & $22,8.1$ & 0.493 \\
\hline
\end{tabular}

\section{Control Variables}

In this section, we describe the coding scheme for the control variables that will be introduced into our multivariate models alongside our predictor variables. The 15 -item control variables that we will be describing can be broadly categorized as inmate health history, inmate violence and sex offending history, and inmate institutional conduct history. In the results section, we will be comparing the statistical significance, magnitude of the effect, and directionality of our control variables with our outcome variables. 


\section{1) Inmate Health History}

The control variable medical needs level is a dichotomously coded binary variable that measures inmates need for medical care and treatment as false, no need expressed by inmate (0) and true, inmate has expressed a significant need (1). The control variable substance abuse needs level is a dichotomously coded binary variable that measures inmates need for substance abuse treatment as false, no need expressed by inmate ( 0 ) and true, inmate has expressed a significant need (1). The control variable engages in cardiovascular activity is a dichotomously coded binary variable that measures inmates physical fitness activity as false, inmate does not engage in cardiovascular activity ( 0 ) and true, inmate does engage in cardiovascular activity (1). The control variable engages in strength training is a dichotomously coded binary variable that measures inmates physical fitness activity as false, inmate does not engage in strength training $(0)$ and true, inmate does engage in strength training (1).

\section{2) Inmate Violence and Sex Offending History}

The control variable history of violent crime is a dichotomously coded binary variable that measures the correctional institutions designation of the inmate as false, no history of violence $(0)$ and true, has a history of violence (1). The control variable before the age of 15, inmate started fist fights is a dichotomously coded binary variable that measures the correctional institutions designation of the inmate as false, no history of physical violence before $15(0)$ and true, has a history of physical violence before the age of 15 (1). The control variable before the age of 15, inmate was mean and hurt people or animals is a dichotomously coded binary variable that measures the correctional institutions designation of the inmate as false, no history of harming people or animals before 15 (0) and true, has a history of harming people or animals before 15. The control variable inmate is a known gang member is a dichotomously coded binary variable that measures the correctional institutions designation of the inmate as false, no history of gang activity (0) and true, has a history of gang activity (1). The control variable sex offender needs level is a dichotomously coded binary variable that measures the correctional institutions designation of the inmate as false, no sex offender needs level (0) and true, has a sex offender needs level (1).

\section{3) Institutional Conduct History}

The control variable previously placed in administrative segregation is a dichotomously coded binary variable that measures the past history of inmate placement as false, no history of administrative segregation (0) and true, has a history of administrative segregation (1). The control variable prefers placement in administrative segregation to the general population is a dichotomously coded binary variable that measures the past history of inmate placement as false, does not have preference for administrative segregation (0) and true, has a preference for administrative segregation (1). The control variable victimized weaker inmates is a dichotomously coded binary variable that measures inmate behavior towards other inmates as false, does not victimize weaker inmates (0) and true, inmate has victimized weaker inmates (1).

The control variable appeared frightened by other inmates is a dichotomously coded binary variable that measures inmate behavior towards other inmates as false, is not frightened of other inmates ( 0 ) and true, inmate is frightened of other inmates (1). The control variable been aggressive 
Sriram Chintakrindi, Joel Capellan, Jeremy R. Porter, M. Blake Wilson, Suditi Gupta: Examining the Effects of...

towards staff is a dichotomously coded binary variable that measures inmate behavior as false, inmate is not aggressive towards staff (0) and true, inmate is aggressive towards staff (1). The control variable been victimized by other inmates is a dichotomously coded binary variable that measures inmate victimization experiences as false, never been victimized by other inmates ( 0 ) and true, inmate has been victimized by other inmates (1).

\section{Analysis Plan}

For this study, we will begin by providing descriptive statistics using frequency and percentages for the predictor, outcome, and control variable. Next, we will be conducting bivariate statistical analysis using Independent sample $t$-tests and Pearson $r$ correlation test of the administrative segregation and suicidal ideation outcomes with our predictor variables for the purpose of identifying marginally or statistically significant relationships with an alpha value of less than 0.10 .

Finally, using the predictor variables that we found to be theoretically relevant in the extant literature, we will then create multivariate models to specify our hierarchical logistic regression for predicting inmate placement in administrative segregation and their risk for suicidal ideation. Hierarchical regression is used when there is a lack of independence across levels of clustered data.

\section{Missing Data}

For this study, given the extremely low-level of missing data, as indicated in the Table 4, we imputed data for cases with missing predictor, control, and outcome variables by using mode imputation because all of our data for our analysis is discrete and categorical. The most frequently designated attributes for each variable with missing data was designated as the method for modal imputation of missing data.

Table 4. Summary of missing data from outcomes, predictor, and control variables

\begin{tabular}{|c|c|}
\hline Variable (Groupings) & Missing data $n(\%)$ \\
\hline \multicolumn{2}{|l|}{$N=270$} \\
\hline \multicolumn{2}{|l|}{ Outcome variables } \\
\hline Group (general population or asministrative segregation) & $0(0)$ \\
\hline I have said I would kill mayself, or tried to, more than once in my life & $1(<1)$ \\
\hline Predictor Variables & Range of missing data $n(\%)$ min. to $n(\%) \max$. \\
\hline Psychiatric disorder symptoms factor score (9-items) & $11(4)$ to $11(4)$ \\
\hline Brain injury and disease symptoms factor score (18-items) & $0(0)$ to $1(<1)$ \\
\hline Low self-control characteristics factor score (22-items) & $0(0)$ to $2(<1)$ \\
\hline \multicolumn{2}{|l|}{ Control variable sub-categories } \\
\hline Inmate Health history (4-items) & $0(0)$ to $10(4)$ \\
\hline Inmate Violance and Sex Offending history (5-items) & $0(0)$ to $0(0)$ \\
\hline Institutional Conduct history (6-items) & $0(0)$ to $19(7)$ \\
\hline
\end{tabular}




\section{RESULTS}

The descriptive statistics set out in the Table 5 for control variables of Institutional Conduct History indicate that $22.6 \%$ of inmates have been previously placed in administrative segregation, $44.4 \%$ prefer administrative segregation to being housed in general population, $24.1 \%$ have victimized weaker inmates, $15.9 \%$ have appeared frightened of other inmates, $29.3 \%$ have been aggressive towards staff, and $8.5 \%$ have been victimized by other inmates.

Table 5. Descriptive statistics of control and predictor variables

\begin{tabular}{|c|c|c|c|}
\hline Variable (Groupings) & $\begin{array}{l}\text { True } \\
\text { n (\%) }\end{array}$ & $\begin{array}{l}\text { False } \\
\mathrm{n}(\%)\end{array}$ & $\mathrm{M}(\mathrm{SD})$ \\
\hline \multicolumn{4}{|l|}{$\begin{array}{l}N=270 \\
\text { Predictor and control variables }\end{array}$} \\
\hline \multicolumn{4}{|l|}{ Inmate Health History } \\
\hline Medical needs level & $48(17.8)$ & $222(82.2)$ & - \\
\hline Substance abuse needs level & $211(78.1)$ & $59(21.9)$ & - \\
\hline Engages in cardiovascular activity & $231(85.6)$ & $39(14.4)$ & - \\
\hline Engages in strength training & $233(86.3)$ & $37(13.7)$ & - \\
\hline \multicolumn{4}{|l|}{ Inmate violence and Sex Offending History } \\
\hline History of violent crime & $166(61.5)$ & $104(38.5)$ & - \\
\hline Before the age of 15 , inmate started first fights & $201(74.4)$ & $69(25.6)$ & - \\
\hline Before the age 15 , inmate was mean and hurt people or animals & $141(52.2)$ & $129(47.8)$ & - \\
\hline Inmate is a known gang member & $159(58.9)$ & $111(41.1)$ & - \\
\hline Sex offender needs level & $86(31.9)$ & $174(68.1)$ & - \\
\hline \multicolumn{4}{|l|}{ Institutional Conduct History } \\
\hline Previously placed in a administrative segregation & $61(22.6)$ & $209(77.4)$ & - \\
\hline Prefers placement in administrative segregation to the general population & $120(44.4)$ & $150(55.6)$ & - \\
\hline Victimized weaker inmates & $65(24.1)$ & $205(75.9)$ & - \\
\hline Appeared frightened of other inmates & $43(15.9)$ & $227(84.1)$ & - \\
\hline Been aggressive towards staff & $79(29.3)$ & $191(70.7)$ & - \\
\hline Been victimized by other inmates & $23(8.5)$ & $247(91.5)$ & - \\
\hline \multicolumn{4}{|l|}{ Predictor Variables } \\
\hline Psychiatric disorder symptoms factor score & - & - & $0(1)$ \\
\hline Brain injury and disease symptoms factor score & - & - & $0(1)$ \\
\hline Low self-control characteristics factor score & - & - & $0(1)$ \\
\hline
\end{tabular}

The descriptive statistics for outcome variables, in the Table 6, indicate that self-report suicidal ideation outcomes apply to $33.0 \%$ of inmates who have said they would kill themselves, or tried to, more than once in their lives and $67 \%$ have indicated never threatening or attempting suicide.

Table 6. Descriptive statistics of outcome variables

\begin{tabular}{|c|c|c|c|}
\hline Variable (Groupings) & $\mathrm{n}(\%)$ & $\begin{array}{c}\text { Yes, atleast one } \\
\text { time } \\
n(\%)\end{array}$ & $\begin{array}{l}\text { Never } \\
n(\%)\end{array}$ \\
\hline \multicolumn{4}{|l|}{$\begin{array}{l}N=270 \\
\text { Outcome variables }\end{array}$} \\
\hline \multicolumn{4}{|l|}{ Study group } \\
\hline General Population Offenders (with and without mental illness) & $143(53)$ & - & - \\
\hline Administratiove Segregation (with and without mental illness) & $127(47)$ & - & - \\
\hline \multicolumn{4}{|l|}{ Self-reported suicidal ideations } \\
\hline I have said I would kill myself, or tried to, more than once in my life & - & $89(33.0)$ & $181(67.0)$ \\
\hline
\end{tabular}


Sriram Chintakrindi, Joel Capellan, Jeremy R. Porter, M. Blake Wilson, Suditi Gupta: Examining the Effects of...

In the Table 7, we present our results from a Pearson $r$ correlation test between our three factor scores. For our first analysis we found a statistically significant, positive correlation, between Psychiatric disorder symptoms and Brain injury and disease symptoms $(r=.370, p<0.001)$. In the second analysis we found a statistically significant, positive correlation, between Psychiatric disorder symptoms and Low self-control characteristics $(r=.332, p<0.001)$. In the final analysis we found a statistically significant, positive correlation, between Brain injury and disease symptoms and Low self-control characteristics $(r=.752, p<0.001)$.

Table 7. Pearson's correlation of predictor variable factor scores

\begin{tabular}{|c|c|c|c|}
\hline$N=270$ & 1 & 2 & 3 \\
\hline 1. Psychiatric disorder symptoms factor score & - & - & - \\
\hline 2. Brain injury and disease symptoms factor score & $.370^{* \star *}$ & - & - \\
\hline 3. Low self-control characteristics factor score & $.332^{* \star *}$ & $.752^{\star \star \star}$ & - \\
\hline
\end{tabular}

${ }^{*} p<0.05,{ }^{* *} p<0.01,{ }^{* * *} p<0.001$

\section{Comparing Factor Score Differences between Inmates from General Population v. Administrative Segregation}

In the Table 8, we present the results of our Independent Sample $t$-test results where we examined mean differences, using our three factor scores variables, between the respondents who reported being in general population versus administrative segregation. Inmates who reported being in the general population had significantly more severe symptoms of psychiatric illness compared to inmates who were placed in administrative segregation $(p<0.01)$. Additionally, inmates who reported being in the general population had significantly more severe symptoms of brain injury compared to inmates who were placed in administrative segregation $(p<0.01)$. We found no statistically significant difference in mean factor scores for low self-control characteristics between inmates in general population versus inmates in administrative segregation $(p>0.05)$.

Table 8. Independent sample t-tests examining predictor variable factor scores for mean differences in inmate institutional placement and self-reported suicidal ideation

\begin{tabular}{|c|c|c|c|c|c|c|}
\hline & $\begin{array}{l}\text { Psychiatric disorder } \\
\text { symptoms factor } \\
\text { score }\end{array}$ & & $\begin{array}{c}\text { Brain injury } \\
\text { diseasse symptoms } \\
\text { factor score }\end{array}$ & & $\begin{array}{l}\text { Low self-control } \\
\text { characteristics } \\
\text { factor score }\end{array}$ & \\
\hline Variables & [Mean $(\mathrm{n}, \mathrm{SD})]$ & $p$-value & [Mean $(\mathrm{n}, \mathrm{SD})]$ & $p$-value & [Mean $(\mathrm{n}, \mathrm{SD})]$ & $p$-value \\
\hline \multicolumn{7}{|l|}{$N=270$} \\
\hline \multicolumn{7}{|l|}{ Group } \\
\hline $\begin{array}{l}\text { General Population Offenders (with and } \\
\text { without mental illness) }\end{array}$ & $0.156(143,1.10)$ & $0.005^{\star *}$ & $0.166(143,1.04)$ & $0.003^{* *}$ & $\begin{array}{c}0.0768143 \\
1.04)\end{array}$ & 0.181 \\
\hline $\begin{array}{l}\text { Administratiove Segregation (with and } \\
\text { without mental illness) }\end{array}$ & - $0.17(127,0.83)$ & & $-0.18(127,0.91)$ & & $-0.08(127,0.93)$ & \\
\hline \multicolumn{7}{|l|}{$\begin{array}{l}\text { I have said I would kill myself, or tried } \\
\text { to, more than once in my life }\end{array}$} \\
\hline Never & $-0.25(181,0.83)$ & $0.000^{* *}$ & $-0.26(181,0.92)$ & $0.000^{* *}$ & - $0.26(181,0.94)$ & $0.000^{* *}$ \\
\hline Yes, at least one time & $0.525(89,1.10)$ & & $0.547(89,0.92)$ & & $0.532(89,0.88)$ & \\
\hline
\end{tabular}

$f p<0.10,{ }^{*} p<0.05,{ }^{* *} p<0.01$ 


\section{Comparing Factor Score Differences between Inmates who Indicated Suicidal Ideation v. Inmates who Did Not Indicate Suicidal Ideation using the Self-Report Indicator "I Have Said I Would Kill Myself, or Tried to, More Than Once in My Life"}

In the Table 8, we present the results of our Independent Sample $t$-tests where we examined mean differences, using our three factor scores variables, between inmates who reported never threatening or attempting suicide versus inmates who reported yes, at least one time threatening or attempting suicide. These results indicate that those inmates who reported yes, at least one time threatening or attempting suicide had significantly more severe symptoms of psychiatric illness compared to inmates who reported never, threatening or attempting suicide $(p<0.01)$. Inmates who reported yes, at least one time threatening or attempting suicide had significantly more severe symptoms of brain injury symptoms compared to inmates who reported never threatening or attempting suicide $(p<0.01)$. Inmates who reported yes, at least one time threatening or attempting suicide had significantly lower levels of self-control characteristics compared to inmates who reported never, threatening or attempting suicide $(p<0.01)$.

In the Table 9, we conducted a hierarchical logistic regression on three models in order to examine the odds-ratio of predictor and control variables on institutional placement of inmates in administrative segregation. In particular, we are interested in examining the magnitude and direction of the relationship of the factor scores for psychiatric disorder symptoms, brain injury symptoms, and low self-control characteristics towards predicting institutional placement of inmates in general population versus administrative segregation. In the first model, we only enter in our control variables. In the second model, we only enter in our predictor variables. In our third and final model we enter in both our predictor and control variables. We found that all of our logistic regression models are statistically significant for predicting inmate institutional placement $(p<0.01)$. 
Sriram Chintakrindi, Joel Capellan, Jeremy R. Porter, M. Blake Wilson, Suditi Gupta: Examining the Effects of...

Table 9. Logistic regression results for examining predictor and control variable effects on institutional placement of inmates in administrative segregation

\begin{tabular}{|c|c|c|c|}
\hline Variable (Groupings) & $\begin{array}{c}\text { Model } 1 \\
\text { Exp (B) }\end{array}$ & $\begin{array}{c}\text { Model } 2 \\
\text { Exp (B) }\end{array}$ & $\begin{array}{c}\text { Model } 3 \\
\text { Exp (B) }\end{array}$ \\
\hline \multicolumn{4}{|l|}{$N=270$} \\
\hline Medical need & 0.946 & - & 1.109 \\
\hline Substance abuse need & 1.031 & - & 1.130 \\
\hline I do cardiovascular activity (jogging, running, speed walking, etc.) & 0.868 & - & 0.747 \\
\hline I do strength training (weight lifting, pull-ups, push-ups, etc.) & $3.51^{*}$ & - & $3.51^{*}$ \\
\hline Record of being involved in violent crime? & $2.14^{*}$ & - & $2.09 *$ \\
\hline Before the age of 15, I often started first fights & 0.730 & - & 0.713 \\
\hline Before the age of 15 , I was mean and hurt people or animals & $2.23^{*}$ & - & $2.44^{\star \star}$ \\
\hline Gang membership & $1.82+$ & - & 1.563 \\
\hline Sex offender need & 1.360 & - & 1.465 \\
\hline Previously placed in administrative segregation & $4.56^{\star \star \star}$ & - & $4.26^{\star \star \star}$ \\
\hline I prefer administrative segregation to the general population & 1.189 & - & 1.327 \\
\hline Victimized weaker inmates & $2.33^{*}$ & - & $2.14^{*}$ \\
\hline Appeared frightened of other inmates & 1.335 & - & 1.335 \\
\hline Been aggressive towards staff & $2.82^{\star \star}$ & - & $2.76^{\star \star}$ \\
\hline Been victimized by other inmates & 0.925 & - & 0.950 \\
\hline Psychiatric disorder symptoms factor score & - & $0.76+$ & 0.831 \\
\hline Brain injury and disease symptoms factor score & - & $0.61^{*}$ & 0.775 \\
\hline Low self-control factor score & - & 1.330 & 1.030 \\
\hline - 2 Log Likelihood Ration & 303.61 & 359.01 & 299.53 \\
\hline Chi-square & $69.74^{\star \star \star}$ & $14.30^{\star \star}$ & $73.83^{* \star *}$ \\
\hline
\end{tabular}

$+p<0.10,{ }^{*} p<0.05 .{ }^{* *} p<0.01,{ }^{* * *} p<0.001$

In particular, we are interested in comparing the strength of our individual predictor- and control- variables when entering them into our third and final model. We found that inmates who indicated they were previously housed in administrative segregation have an increase in odds of 4.26 times of being placed in administrative segregation compared to inmates who have not been previously placed in administrative segregation $(p<0.01)$. We found that inmates who indicated that they were victimized by other inmates have an increase in odds of 2.14 times of being placed in administrative segregation compared to inmates who did not report victimizing other inmates $(p<0.05)$. We found that inmates who indicated that they were aggressive towards staff have an increase in odds of 2.76 times of being placed in administrative segregation compared to inmates who did not report being aggressive towards staff $(p<0.01)$. However, in our third and final model we did not find statistical significance that our factor scores for psychiatric symptoms, brain injury symptoms, and low self-control characteristics predict institutional placement of inmates in administrative segregation.

In the Table 10, we conducted a hierarchical logistic regression on three models in order to examine the odds-ratio of predictor and control variables on inmate suicidal ideation. In particular, we are interested in examining the magnitude and direction of the relationship of the factor scores for psychiatric disorder symptoms, brain injury symptoms, and low self-control characteristics towards predicting inmate responses to the outcome of "I have said I would kill myself, or tried to, 
more than once in my life". In the first model, we only enter in our control variables. In the second model, we only enter in our predictor variables. In our third and final model we enter in both our predictor and control variables. We found that all of our logistic regression models are statistically significant for predicting inmate suicidal ideation $(p<0.001)$.

Table 10. Logistic regression results for examining predictor and control variable effects on inmates self-reporting "I have said I would kill myself, or tried to, more than once in my life"

\begin{tabular}{|c|c|c|c|}
\hline Variable (Groupings) & $\begin{array}{c}\text { Model } 1 \\
\text { Exp (B) }\end{array}$ & $\begin{array}{l}\text { Model } 2 \\
\text { Exp (B) }\end{array}$ & $\begin{array}{c}\text { Model } 3 \\
\text { Exp (B) }\end{array}$ \\
\hline \multicolumn{4}{|l|}{$N=\mathbf{2 7 0}$} \\
\hline Medical need & $1.96+$ & - & 1.387 \\
\hline Substance abuse need & 1.542 & - & 1.438 \\
\hline I do cardiovascular activity (jogging, running, speed walking, etc.) & $0.32^{*}$ & - & $0.30^{*}$ \\
\hline I do strength training (weight lifting, pull-ups, push-ups, etc.) & 0.504 & - & 0.521 \\
\hline Record of being involved in violent crime? & 0.985 & - & 1.152 \\
\hline Before the age of $15, \mathrm{I}$ often started first fights & 1.085 & - & 1.005 \\
\hline Before the age of 15 , I was mean and hurt people or animals & 1.630 & - & 1.152 \\
\hline Gang membership & $0.44^{*}$ & - & $1.88+$ \\
\hline Sex offender need & 2.13 & - & $1.88+$ \\
\hline Previously placed in administrative segregation & 0.988 & - & 1.185 \\
\hline I prefer administrative segregation to the general population & $2.79 * *$ & - & $2.17^{*}$ \\
\hline Victimized weaker inmates & 1.155 & - & 1.606 \\
\hline Appeared frightened of other inmates & 0.618 & - & 0.539 \\
\hline Been aggressive towards staff & $0.43^{*}$ & - & $0.41^{*}$ \\
\hline Been victimized by other inmates & 2.131 & - & 2.379 \\
\hline Psychiatric disorder symptoms factor score & - & $1.87^{* * *}$ & $1.70^{\star *}$ \\
\hline Brain injury and disease symptoms factor score & - & $1.49+$ & 1.078 \\
\hline Low self-control factor score & - & $1.60^{*}$ & $1.86^{*}$ \\
\hline - 2 Log Likelihood Ration & 278.78 & 278.96 & 248.79 \\
\hline Chi-square & $63.54^{\star * *}$ & $63.36^{\star \star *}$ & $93.53^{* * *}$ \\
\hline
\end{tabular}

$+p<0.10,{ }^{*} p<0.05 .{ }^{* *} p<0.01,{ }^{* \star *} p<0.001$

In particular, we are interested in comparing the strength of our control variables when entering them into our third and final model. We found that inmates who indicated they prefer being housed in administrative segregation have an increase in odds of 2.17 times of reporting that they had at least one time contemplated committing suicide compared to inmates who have not been previously placed in administrative segregation $(p<0.05)$. We found that inmates who indicated that they were aggressive towards staff have a decrease in odds of 0.41 times of reporting that they had at least one time contemplated committing suicide compared to inmates who did not report being aggressive towards staff $(p<0.05)$.

In our third and final model we found statistical significance for our factor scores for psychiatric symptoms and low self-control characteristics for predicting inmate suicidal ideation. More specifically, we found that inmates with higher factor scores for psychiatric disorder symptoms have a higher likelihood of reporting that they had at least one time contemplated committing suicide by 1.70 times $(p<0.01)$. Similarly, we found that inmates with higher factor scores for low 
self-control characteristics have a higher likelihood of reporting that they had at least once contemplated committing suicide by 1.86 times $(p<0.05)$.

\section{CONCLUSION}

\section{Discussion}

After completing a comprehensive analysis of our inmate data, we found empirical evidence to suggest that our factor score constructs for two of our theoretical variables, psychiatric symptoms and low self-control characteristics, are statistically significant predictors of suicidal ideation among inmates. However, our research findings also demonstrate mixed results regarding the use of our theoretical constructs for predicting inmate institutional placement in administrative segregation, for which we found no statistical significance. Therefore, the results from this study suggest that alternative psychosocial constructs need to be explored in order to reliably explain both inmate institutional placement in administrative segregation and inmate risk for suicidal ideation.

Although our theoretical constructs were not reliably predictive of both inmate placement in administrative segregation and inmate risk for suicidal ideation, we did find that a number of our control variables were consistent at predicting our outcome variables. We found that previous placement in administrative segregation is a reliable predictor of current inmate placement in administrative segregation. Additionally, we found that inmates who had a history of violence before the age of 15 and who were aggressive towards staff were two times as likely to be placed in administrative segregation compared to those inmates that did not report a history of violence. When examining the control variables from our models that were predictive of suicidal ideation, we found that inmates who were previously placed in administrative segregation and who have been identified as having sex offender needs were two times as likely to report experiencing suicidal ideation compared to those who did not self-report those indicators.

Therefore, we have reason to believe that inmates with a history of aggression, history of placement in administrative segregation, and sex offender needs have a higher likelihood of placement in administrative segregation and expressing suicidal ideation. The results from the analysis of our control variables provides us with a strong foundation for setting up future research that allows us to continue to examine the causes of what Durkheim (1897) would notably conceptualize as "fatalistic suicide."

Understanding the effects of psychiatric symptoms, brain injury, and low self-control characteristics among inmates is essential to ensuring the public health of inmates, safety of correctional officers, and protecting safety and health of the respective communities in which inmates reenter after completing their sentences. Examining the effects of inmate mental health and self-control traits through a neuropsychiatric and criminological theoretical framework is a vital component for developing risk-assessments, diagnostic instruments, and treatment interventions (Chintakrindi, Porter, Mellow, \& Sung, 2015). 
Studies examining inmate behavioral health outcomes allow academic researchers and practitioners to mitigate inmate behavioral risk factors through developing targeted interventions and improving the efficacy of treatment (Andrews and Bonta, 2010). Although there have been significant improvements in screening for mental health, substance use, and anger management issues among incarcerated inmates, there continues to be a lack of effective screening and interventions for TBI. Based on the findings from our study, our policy recommendations include incorporating, in correctional and community settings, routine screening procedures and interventions that focus on TBI and neuropsychiatric symptoms using psychopharmacological interventions, cognitive behavioral therapy, and vocational rehabilitation programming to reduce the alarming incidence of behavioral problems, mood disorders, and violence among inmates (Slaughter, Fann, and Ehde, 2003; Chintakrindi, Upton, Louison, \& Case, 2013; Chintakrindi, Porter, Kim, \& Gupta, 2015).

\section{Limitations}

The following data was de-identified due to ethical considerations and is not publicly available within the datasets on ICPSR: age, race, education level, sentence length, total convictions, total number of incarcerations, and mandatory release date. Therefore, we were unable to measure and control for important socio-demographic and criminal case history characteristics. Additionally, we used modal imputation to complete data that was missing among our specified predictor, outcome, and control variables. Although we observe limitations associated with having no baseline demographic characteristics and missing data, we remain confident that our case-control design and imputation method will allow us to generate valid and reliable interpretable results for measuring the magnitude of the effect that the relationship between inmate neuropsychiatric and criminological characteristics has on inmate risk for placement in administrative segregation and suicidal ideation.

\section{REFERENCES}

Andrews, D. A., \& Bonta, J. (2010). The psychology of criminal conduct. Routledge.

Baumgartner, F., Davidson, M., Johnson, K., Krishnamurthy, A., \& Wilson, C. (2017). Deadly justice: a statistical portrait of the death penalty. Oxford University Press.

Camus, A. (2013). The myth of Sisyphus. Penguin UK.

Chintakrindi, S, \& Porter, J. (2016). Assisted Suicide and the Death Penalty: Examining Attitudes towards State Sanctioned Death. Criminology \& Social Integration, 24(2), 1-23.

Chintakrindi, S., Porter, J. R., Mellow, J., \& Sung, H. E. (2015). Empirical test of low self-control theory using post-treatment substance use and recidivism outcomes of parolees participating in an experimental intervention. Criminology, Criminal Justice, Law \& Society, 16(2), 14-41.

Chintakrindi, S., Porter, J., Kim, C., \& Gupta, S. (2015). An Examination of Employment and Earning Outcomes of Probationers With Criminal and Substance Use Histories. SAGE Open, 5(4), 2158244015616662. 
Chintakrindi, S., Upton, A., Louison, A. M., Case, B., \& Steadman, H. J. (2013). Transitional case management for reducing recidivism of individuals with mental disorders and multiple misdemeanors. Psychiatric Services, 64(9), 915-917.

Coolidge, F. L. (2004). Coolidge Correctional Inventory. Colorado Springs, CO: Author.

Coolidge, F. L., Marle, P. D., Van Horn, S. A., \& Segal, D. L. (2011). Clinical syndromes, personality disorders, and neurocognitive differences in male and female inmates. Behavioral sciences \& the law, 29(5), 741-751.

Coolidge, F. L., Segal, D. L., Klebe, K. J., Cahill, B. S., \& Whitcomb, J. M. (2009). Psychometric properties of the Coolidge Correctional Inventory in a sample of 3,962 prison inmates. Behavioral sciences \& the law, 27(5), 713-726.

Durkheim, E. (1951). Suicide: a study in sociology [1897]. Translated by JA Spaulding and G. Simpson (Glencoe, Illinois: The Free Press, 1951).

Gottfredson, M. R., \& Hirschi, T. (1990). A General Theory of Crime. Stanford, California: Stanford University Press.

Grasmick, H., Tittle, C., Bursik, R., and Arneklev, B. (1993) Testing the core empirical implications of Gottfredson and Hirschi's general theory of crime. Journal of Research in Crime and Delinquency, 30, 5-29.

Grassian, S. (2006). Psychiatric effects of solitary confinement. Washington University Journal of Law \& Policy, 22, 325.

Gunter, T. D., Chibnall, J. T., Antoniak, S. K., Philibert, R. A., \& Black, D. W. (2013). Childhood trauma, traumatic brain injury, and mental health disorders associated with suicidal ideation and suicide-related behavior in a community corrections sample. Journal of the American Academy of Psychiatry and the Law Online, 41(2), 245-255.

Hagan, B. O., Wang, E. A., Aminawung, J. A., Albizu-Garcia, C. E., Zaller, N., Nyamu, S., Shavit, S., Deluca, J., \& Fox, A. D. (2017). History of Solitary Confinement Is Associated with Post-Traumatic Stress Disorder Symptoms among Individuals Recently Released from Prison. Journal of Urban Health, 1-8.

Haney, C. (2003). Mental health issues in long-term solitary and "supermax" confinement. Crime \& Delinquency, 49(1), 124-156.

Haney, C., \& Zimbardo, P. (1998). The past and future of US prison policy: Twenty-five years after the Stanford Prison Experiment. American Psychologist, 53(7), 709.

Jenkins, G. R., Hale, R., Papanastassiou, M., Crawford, M. J., \& Tyrer, P. (2002). Suicide rate 22 years after parasuicide: cohort study. BMJ: British Medical Journal, 325(7373), 1155.

Kaba, F., Lewis, A., Glowa-Kollisch, S., Hadler, J., Lee, D., Alper, H., Selling, D., MacDonald, R., Solimo, A., Parsons, A., Venters, H., \& Venters, H. (2014). Solitary confinement and risk of self-harm among jail inmates. American journal of public health, 104(3), 442-447.

Lanes, E. C. (2011). Are the "worst of the worst" self-injurious prisoners more likely to end up in long-term maximum-security administrative segregation?. International journal of offender therapy and comparative criminology, 55(7), 1034-1050.

Lewis, D. O., Pincus, J. H., Feldman, M., Jackson, L., \& Bard, B. (1986). Psychiatric, neurological, and psychoeducational characteristics of 15 death row inmates in the United States. American journal of psychiatry, 143(7), 838-845. 
Linehan, M. M., \& Nielsen, S. L. (1981). Assessment of suicide ideation and parasuicide: Hopelessness and social desirability. Journal of Consulting and Clinical Psychology, 49(5), 773.

Metzner, J. L., \& Fellner, J. (2010). Solitary Confinement and Mental Illness in US Prisons: A Challenge for Medical Ethics. Journal of the American Academy of Psychiatry and the Law Online, 38(1), 104-108.

O'Keefe, M. L. (2008). Administrative segregation from within a corrections perspective. The Prison Journal, 88(1), 123-143.

O'Keefe, M. L., \& Klebe, K. (2014). Evaluation of the Psychological Effects of Administrative Segregation in Colorado, 2007-2010. ICPSR31321-v1. Ann Arbor, MI: Inter-university Consortium for Political and Social Research [distributor]. https://doi.org/10.3886/ICPSR31321.v1

O'Keefe, M. L., Klebe, K. J., Stucker, A., Sturm, K., \& Leggett, W. (2010). One year longitudinal study of the psychological effects of administrative segregation. Colorado Department of Corrections, Office of Planning and Analysis.

Siegler, A., Rosner, Z., MacDonald, R., Ford, E., \& Venters, H. (2017). Head trauma in jail and implications for chronic traumatic encephalopathy in the United States: case report and results of injury surveillance in NYC jails. Journal of health care for the poor and underserved, 28(3), 1042-1049.

Slaughter, B., Fann, J. R., \& Ehde, D. (2003). Traumatic brain injury in a county jail population: prevalence, neuropsychological functioning and psychiatric disorders. Brain Injury, 17(9), 731-741.

Sung, H. E. (2010). Prevalence and risk factors of violence-related and accident-related injuries among state prisoners. Journal of Correctional Health Care, 16(3), 178-187.

Sung, H. E., \& Richter, L. (2006). Contextual barriers to successful reentry of recovering drug offenders. Journal of substance abuse treatment, 31(4), 365-374.

Sung, H. E., Mellow, J., \& Mahoney, A. M. (2010). Jail inmates with co-occurring mental health and substance use problems: Correlates and service needs. Journal of Offender Rehabilitation, 49(2), 126-145. 


\title{
ISPITIVANJE UČINAKA PSIHIJATRIJSKIH SIMPTOMA, SIMPTOMA TRAUMATSKE OZLJEDE MOZGA I NISKE RAZINE SAMOKONTROLE NA OSAMLJENJE I POJAVU SUICIDALNIH MISLI KOD ZATVORENIKA
}

\author{
Sriram Chintakrindi
}

California State University, Stanislaus

Joel Capellan

Rowan University

Jeremy R. Porter

Brooklyn College, CUNY

M. Blake Wilson

California State University, Stanislaus

Suditi Gupta

California State University, Stanislaus, Modesto Junior College

\begin{abstract}
SAŽETAK
Svrha: U ovoj studiji želimo istražiti prediktivne učinke psihijatrijskih simptoma, simptoma traumatske ozljede mozga i kriminoloških čimbenika na rizik izricanja osamljenja i pojavu suicidalnih misli kod zatvorenika ( $N=270)$.

Metode: Koristeći kauzalno-komparativni nacrt, u ovom istraživanju nastojimo razumjeti psihološke i bihevioralne profile rizika kod zatvorenika kojima je određeno osamljenje i onih koji imaju suicidalne misli. Konkretno, nastojimo razumjeti koliki učinak psihijatrijski simptomi, simptomi traumatske ozljede mozga i niska razina samokontrole imaju na izricanje osamljenja i pojave suicidalnih misli kod zatvorenika.

Rezultati: Zaključili smo da vrijednosti čimbenika za psihijatrijske simptome i nisku razinu samokontrole značajno povećavaju rizik od pojave suicidalnih misli kod zatvorenika u usporedbi s ostalim prediktivnim čimbenicima.

Ključne riječi: psihijatrijski simptomi, traumatska ozljeda mozga, niska razina samokontrole, mjere osamljenja, suicidalne misli
\end{abstract}

